\title{
Blastocyst classification systems used in Latin America: is a consensus possible?
}

\author{
Tatiana Puga-Torres ${ }^{1}$, Xavier Blum-Rojas ${ }^{1}$, Medardo Blum-Narváez ${ }^{1}$ \\ ${ }^{1}$ Assisted Reproduction National Center INNAIFEST - Guayaquil - Ecuador
}

\begin{abstract}
Objective: To identify different blastocyst classification systems used by embryologists in Latin American countries and evaluate the possibility of establishing a consensus among these countries.

Methods: An E-mail survey was carried out through the Latin American Network of Assisted Reproduction (REDLARA) aimed at embryologists from assisted reproduction centers in Latin countries.

Results: Sixty surveys were collected from 12 Latin American countries, of which $66.7 \%$ had $>10$ years of professional practice as embryologists. Seven different blastocyst classification systems were reported, of which 5 have previously been described in the literature.

Conclusion: Although the group of embryologists surveyed use different blastocyst classification systems, most in this group consider that the embryo score system should be unified in their countries as well as in the region.
\end{abstract}

Keywords: blastocyst, consensus, Latin America

\section{INTRODUCTION}

The selection of the best embryo within a cohort of embryos is a crucial step for in vitro fertilization treatment (IVF) (Balaban et al., 2006; Santos Filho et al., 2012; Nasiri \& Eftekhari-Yazdi, 2015). This has led to the development of different embryonic qualification systems, from morphological, biochemical and time-lapse systems (Richardson et al., 2015; Hossain et al., 2016); however, the system based on development rate and morphology assessment using light microscopy remains the embryo selection system mostly employed by IVF clinics worldwide (Alpha Scientists in Reproductive Medicine \& ESHRE Special Interest Group of Embryology, 2011).

Several systems of morphological classification of embryos and blastocysts have been developed (Balaban et al., 2006; Mackenna et al., 2013; Hossain et al., 2016), from simple systems with one-degree assignment to complex systems using formulas to predict the likelihood of a pregnancy (Matsuura et al., 2010; Racowsky et al., 2010).

In the case of blastocysts, the evaluation and morphological classification usually considers the morphology of the inner cell mass (ICM), the morphology of the trophectoderm (TE) and cavity expansion (Balaban et al., 2006; Racowsky et al., 2010; Hill et al., 2013). Some of the systems published for classification of Blastocysts include Gardner (Gardner et al., 2000; 2004; Balaban et al., 2006), Veeck \& Zaninovic (2003), Cecilia Sjoblom (Richardson et al., 2015).

Considering the variety of morphological systems for embryonic classification (Alpha Scientists in Reproductive Medicine \& ESHRE Special Interest Group of Embryology, 2011), some countries and organizations have reached a consensus to standardize the morphological classification system of the embryos (Santos Filho et al., 2012).

Countries like the United Kingdom and Spain use a standardized national method of blastocyst classification (Hossain et al., 2016). In Spain, the Association for the Study of Biology of Reproduction - ASEBIR, published in 2015, the third edition of the ASEBIR Criteria for Morphological Assessment of Oocytes, Early Embryos and Human Blastocysts (ASEBIR, 2015). The Society for Assisted Reproductive Technology (SART) adhered to the embryo morphological evaluation system based on three categories: Good, Fair and Poor (Racowsky et al., 2010). The European Society of Human Reproduction and Embryology - ESHRE and the Alpha Scientist in Reproductive Medicine, reached a consensus to establish common criteria and terminologies for the classification of oocytes, embryos and blastocyst in Europe (Alpha Scientists in Reproductive Medicine \& ESHRE Special Interest Group of Embryology, 2011).

No records were found regarding a consensus in terms of blastocyst classification systems in Latin America. Therefore, the present study aims to identify the different blastocyst classification systems that are used by embryologists in Latin American countries and evaluate the possibility of establishing a consensus among these countries.

\section{MATERIALS AND METHODS}

A survey was carried out via E-mail through the Latin American Network of Assisted Reproduction (REDLARA) aimed at embryologists from assisted reproduction centers in Latin America. This survey asked for information concerning the country where they practiced their profession, years of experience, the blastocyst classification system used and considerations regarding the unification of embryo score criteria.

\section{RESULTS}

Sixty surveys were collected from 12 Latin American specialists (Figure 1), of whom $66.7 \%$ had $>10$ years of professional practice as embryologists, $21.7 \%$ from 5 to 10 years and $11.7 \%<5$ years.

Seven different blastocyst classification systems (Figure 2) were reported among the embryologists surveyed. Five of these systems have been previously listed: Gardner and Schoolcraft (Table 1), Veeck (Table 2), ASEBIR (Table 3), Istanbul Consensus (Table 4) and Sjoblom (Table 5). In Brazil and Argentina, the Gardner system is the most used among the embryologists surveyed, while Mexican embryologists use the ASEBIR criteria (Figure 3 ).

Of the 5 previously published systems, the Istanbul consensus system has a numerical score, while the ASEBIR and Sjoblom systems are alphabetic. Gardner and Veeck systems are alphanumeric. 


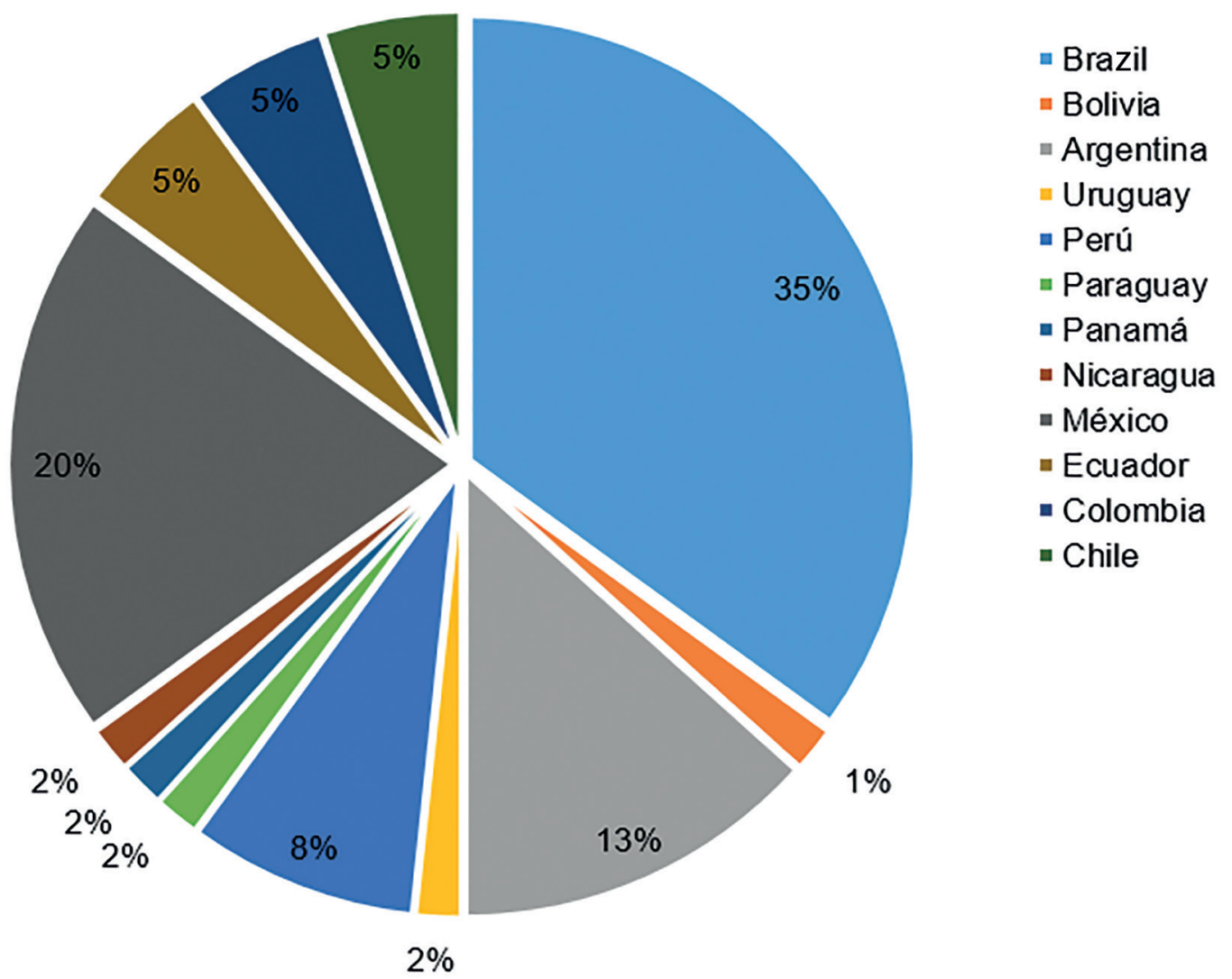

Figure 1. A: Countries where the embryologists surveyed work.

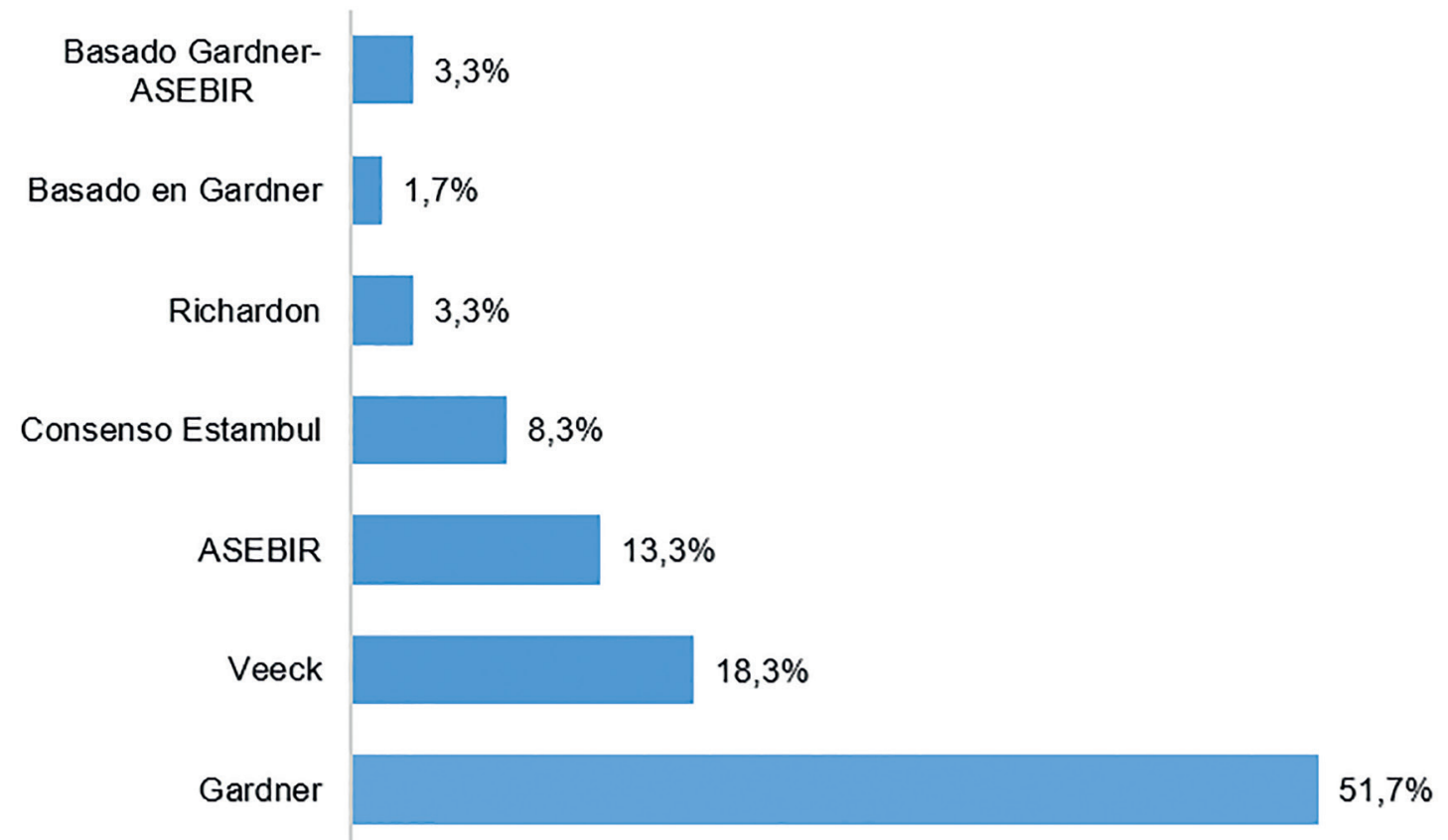

Figure 2. Blastocyst classification systems used among embryologists (Percentage). 
Table 1. Gardner and Schoolcraft Classification System (Gardner et al., 2000; 2004)

Size and expansion

\begin{tabular}{|c|l|}
\hline Classification & Description \\
\hline 1 & Early blastocyst: the blastocele is less than half the volume of the embryo \\
\hline 2 & Blastocyst: the blastocele is greater than or equal to half of the volume of the embryo. \\
\hline 3 & Full blastocyst: the blastocele completely fills the embryo. \\
\hline 4 & $\begin{array}{l}\text { Expanded blastocyst: the blastocele volume is larger than that of the early embryo and the zona } \\
\text { pellucida is thinning. }\end{array}$ \\
\hline 5 & Hatching blastocyst: the trophectoderm has started to herniate through the zona pellucida. \\
\hline 6 & Hatched blastocyst: the blastocyst has completely escaped from the zona pellucida. \\
\hline ICM (Inner Cell mass) & \multicolumn{2}{|l}{} \\
\hline Classification & Description \\
\hline A & tightly packed, many cells \\
\hline B & loosely grouped, several cells \\
\hline C & very few cells \\
\hline Trophectoderm (TE) & \multicolumn{2}{|l}{} \\
\hline Classification & Description \\
\hline A & many cells forming a tightly knit epithelium \\
\hline B & few cells \\
\hline C & very few cells forming a loose epithelium \\
\hline
\end{tabular}

(Balaban et al., 2006).

Table 2. Veeck and Zaninovic Classification System

Blastocyst $\geq 50 \%$ cavity/Cavitated morula $<50 \%$ cavity

\begin{tabular}{l|l}
\hline Classification & Description \\
\hline
\end{tabular}

Degree of expansion and hatching status

\begin{tabular}{|c|c|}
\hline 1 & $\begin{array}{l}\text { Early blastocyst; the blastocoel filling more than half the volume of the conceptus, but no expansion } \\
\text { in overall size as compared to earlier stages }\end{array}$ \\
\hline 2 & $\begin{array}{l}\text { Blastocyst; the blastocoel filling more than half of the volume of the conceptus; with slight } \\
\text { expansion in overall size and notable thinning of the zona pellucida. }\end{array}$ \\
\hline 3 & $\begin{array}{l}\text { Full blastocyst; a blastocoel of more than } 50 \% \text { of the conceptus volume and overall size fully } \\
\text { enlarged with a very thin zona pellucida }\end{array}$ \\
\hline 4 & $\begin{array}{l}\text { Hatching blastocyst; non-preimplantation genetic diagnosis. The trophectoderm has started to } \\
\text { herniate through the zona }\end{array}$ \\
\hline 5 & $\begin{array}{l}\text { Fully hatched blastocyst; non-preimplantation genetic diagnosis. Free blastocyst fully removed } \\
\text { from zona pellucida }\end{array}$ \\
\hline 6 & Hatching or hatched blastocyst; preimplantation genetic diagnosis \\
\hline \multicolumn{2}{|c|}{ Inner cell mass (ICM) } \\
\hline A & Tightly packed, compacted cells \\
\hline B & Larger, loose cells \\
\hline $\mathrm{C}$ & No ICM distinguishable \\
\hline $\mathrm{D}$ & Cells if ICM appear degenerative \\
\hline \multicolumn{2}{|c|}{ Trophectoderm (TE) } \\
\hline A & Many healthy cells forming a cohesive epithelium \\
\hline B & Few, but healthy large cells \\
\hline $\mathrm{C}$ & Poor, very large, or unevenly distributed cells, may appear as few cells squeezed to the side \\
\hline D & Cells of the trophectoderm appear degenerative \\
\hline
\end{tabular}

(Veeck \& Zaninovic, 2003). 


\begin{tabular}{|c|c|c|c|}
\hline Grade de Expansion & ICM & $\mathrm{TE}$ & ASEBIR Classification \\
\hline \multirow{13}{*}{$\begin{array}{l}\text { From: "Starting the } \\
\text { expansion" } \\
\text { To: "Hatching/hatched" }\end{array}$} & \multirow{4}{*}{$\begin{array}{c}\text { A } \\
\text { Compacted }\end{array}$} & A & A \\
\hline & & B & $\mathrm{B}$ \\
\hline & & $\mathrm{C}$ & $\mathrm{C}$ \\
\hline & & $\mathrm{D}$ & $\mathrm{D}$ \\
\hline & \multirow{4}{*}{$\begin{array}{c}\text { B } \\
\text { Not Compacted }\end{array}$} & A & A \\
\hline & & $\mathrm{B}$ & $\mathrm{B}$ \\
\hline & & $\mathrm{C}$ & $\mathrm{C}$ \\
\hline & & $\mathrm{D}$ & $\mathrm{D}$ \\
\hline & \multirow{4}{*}{$\begin{array}{c}\mathrm{C} \\
\text { Indifferent }\end{array}$} & A & A \\
\hline & & B & B \\
\hline & & $\mathrm{C}$ & $\mathrm{C}$ \\
\hline & & $\mathrm{D}$ & $\mathrm{D}$ \\
\hline & $\begin{array}{c}\text { D } \\
\text { Signs of degeneration }\end{array}$ & $\mathrm{A}, \mathrm{B}, \mathrm{C}$ o D & $\mathrm{D}$ \\
\hline \multicolumn{3}{|c|}{ Early blastocyst or cavitated (ZP gross) } & $\mathrm{C}$ \\
\hline \multicolumn{3}{|c|}{ Morula } & $\mathrm{C}$ \\
\hline
\end{tabular}

(ASEBIR, 2015).

Table 4. Istanbul Consensus Scoring System for Blastocysts

\begin{tabular}{|c|c|c|c|}
\hline & Grade & Rating & Description \\
\hline \multirow{4}{*}{ Stage of development } & 1 & & Early \\
\hline & 2 & & Blastocyst \\
\hline & 3 & & Expanded \\
\hline & 4 & & Hatched/hatching \\
\hline \multirow{3}{*}{ ICM } & 1 & Good & $\begin{array}{l}\text { Prominent, easily discernible, with many cells that are compacted and } \\
\text { tightly adhered together }\end{array}$ \\
\hline & 2 & Fair & Easily discernible, with many cells that are loosely grouped together \\
\hline & 3 & Poor & Difficult to discern, with few cells \\
\hline \multirow{3}{*}{ TE } & 1 & Good & Many cells forming a cohesive epithelium \\
\hline & 2 & Fair & Few cells forming a loose epithelium \\
\hline & 3 & Poor & Very few cells \\
\hline
\end{tabular}

(Alpha Scientists in Reproductive Medicine \& ESHRE Special Interest Group of Embryology, 2011).

On a scale of 1 to 5 ( 1 easy and 5 difficult), $48.3 \%$ of the respondents considered that the blastocyst classification system used was easy, while $3.3 \%$ considered it difficult (Figure 4 ). In general, $48.3 \%$ of embryologists considered that the system they use to classify blastocysts could be simplified, while $51.7 \%$ believed that this was not possible.

$88.1 \%$ of embryologists believe that the Blastocyst classification system should be unified in their countries and $88.3 \%$ think it should be for the entire region.

\section{DISCUSSION}

Since improvements in culture media gave the possibility of extending embryo culture until days 5 and 6 (Crosby \& Mackenna, 2013; Richardson et al., 2015), the identification of the embryo that will become a viable blastocyst requires a robust scoring system (Gianaroli et al., 2012; Richardson et al., 2015). The classification system of embryos and blastocysts should be simple, composed of fields that are based on scientific research, with a predictive value tested and easily adaptable in laboratories (Racowsky et al., 2010). 
Table 5. Sjoblom Cecilia Classification System

\begin{tabular}{|c|l|}
\hline Classification & Description \\
\hline A & $\begin{array}{l}\text { Expanded blastocyst (blastocele cavity over 50\% of volume), larger than a cleaving stage embryo with a } \\
\text { thinning zona pellucida. Must have a clear inner cell mass and cohesive trophectoderm. }\end{array}$ \\
\hline B & $\begin{array}{l}\text { Fully formed blastocyst with a clear inner cell mass and cohesive trophectoderm but not yet expanded with } \\
\text { a non-thinning zona pellucida. }\end{array}$ \\
\hline C & $\begin{array}{l}\text { Blastocyst with small/no inner cell mass and/or irregular/interrupted trophectoderm and/or excluded/ } \\
\text { degenerate cells. }\end{array}$ \\
\hline Cavitation & Evidence of a cavity of any size forming within the embryo, two distinct cell types not yet visible \\
\hline Compacting & Evidence of any signs of compaction between cells of the embryo. \\
\hline
\end{tabular}

(Richardson et al., 2015).

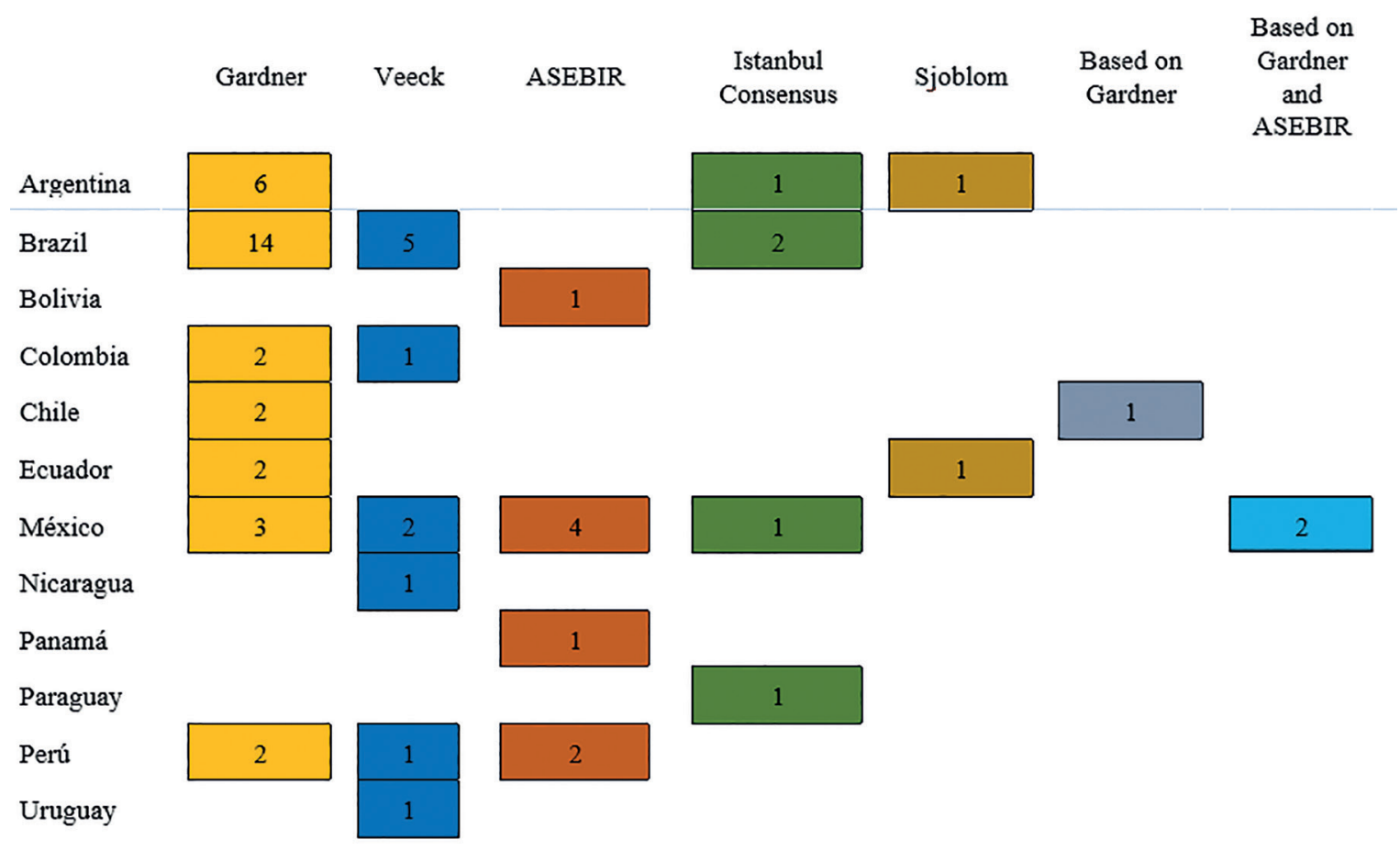

Figure 3. Number of Embryologists using the Classification systems reported.

Considering the variability of the embryo morphological classification systems published, several countries such as Spain as well as organizations such as SART in the United States and ESHRE in Europe have established consensus to standardize embryo qualification criteria for IVF treatments for assisted reproduction centers of those regions; however, no online published records about embryo consensus for assisted reproduction centers in Latin American countries were found.

From our survey, we collected 60 responses of embryologists from Assisted Reproduction Centers from 12 Latin American countries (Figure 1); However, we did not have responses from embryologists working in centers in Costa Rica, Guatemala, Dominican Republic and Venezuela, where there are also one or more centers accredited by REDLARA.

In the group of embryologists surveyed, seven different blastocyst classification systems were reported. The Gardner and Schoolcarft system is the most used among all embryologists surveyed $(51.7 \%)$, being the main system used by embryologists from Argentina and Brazil. In Mexico and Peru there seems to be a greater variability in the use of blastocyst classification systems, with the ASEBIR score being the most used in Mexico (Figure 3). To assert this, it would be necessary to obtain information from a greater number of embryologists from the different countries of Latin America.

The survey also revealed the use of two unpublished blastocyst score systems. Two embryologists indicated the use of a standardized system based on the Gardner's and ASEBIR's criteria, while one embryologist reported the use of his own modified Gardner's system. Considering that the survey was anonymous, it was not possible to obtain information regarding the detailed criteria of these systems.

When comparing the five different criteria used by the surveyed embryologists, we can realize that there is variability in several points. The Istanbul consensus system is numerical, whereas ASEBIR and Sjoblom are alphabetic, and Gardner and Vecck are alphanumeric. Although the scoring criteria of the five systems already published include the expansion evaluation, the ICM and the TE of the blastocysts, the score for these characteristics has variations between the different systems (Table 6). 


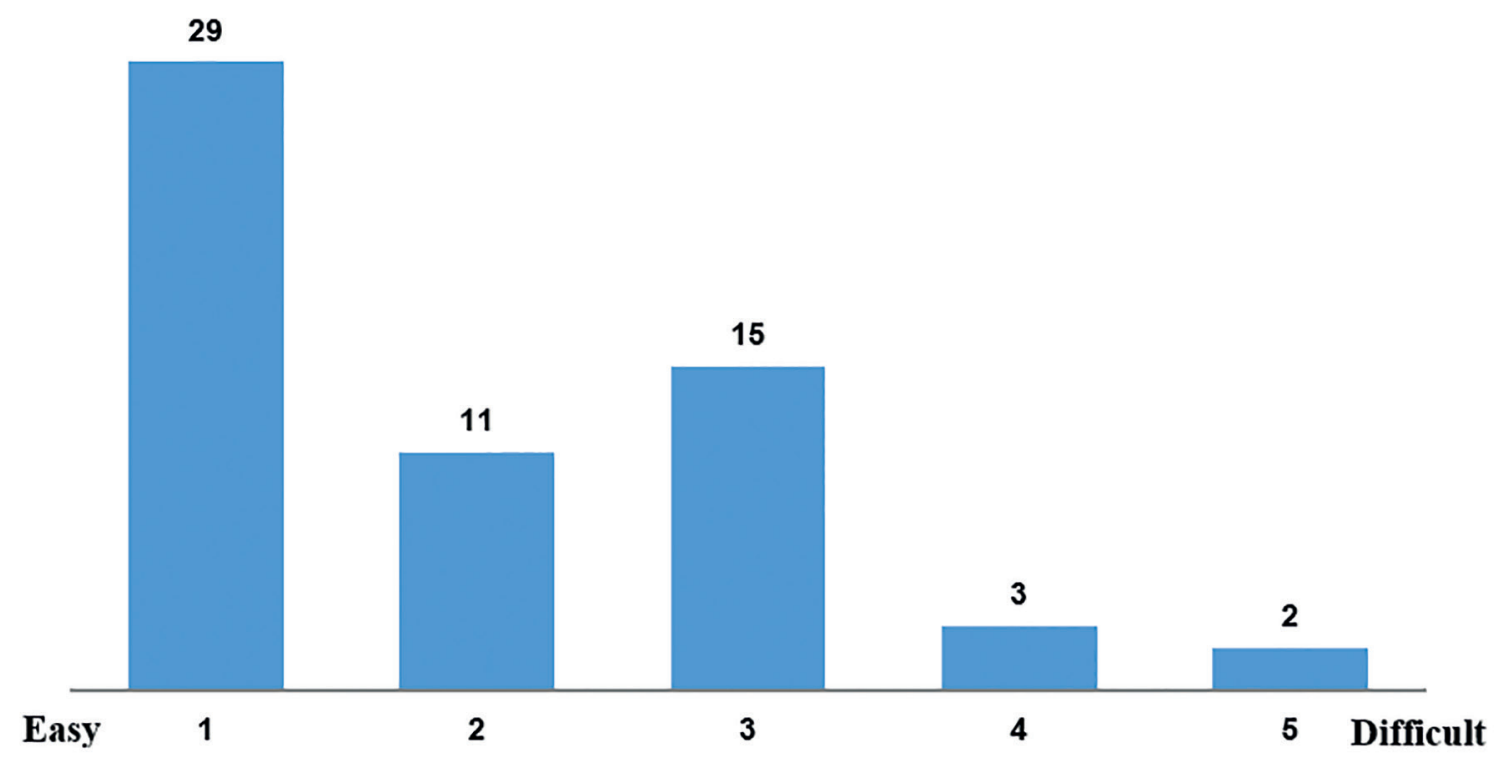

Figure 4. Difficulty Perceived Concerning the Blastocyst Classification System used: Number of embryologists.

Table 6. Score Variation between 5 different blastocyst classification systems

\begin{tabular}{|c|c|c|c|c|c|}
\hline & Gardner & Veeck & $\begin{array}{c}\text { Istanbul } \\
\text { Consensus }\end{array}$ & ASEBIR & Sjoblom \\
\hline \multirow{8}{*}{ Expansion } & - & - & - & - & Compacting \\
\hline & 1 & $\begin{array}{c}\text { Morula } \\
\text { cavitation }\end{array}$ & 1 & \multirow{6}{*}{$\begin{array}{c}\text { From } \\
\text { initiating } \\
\text { expansion } \\
\text { to } \\
\text { hatched }\end{array}$} & \multirow{15}{*}{$\begin{array}{l}\text { A: 4AA (Garder), 3AA (Veeck), } 311 \\
\text { (Istanbul consensus), AA - BA - CA } \\
\text { (ASEBIR) } \\
\text { B: 3AA (Garder), 1BB-2BB (Veeck), } \\
322 \text { (Istanbul consensus), AB - BB - } \\
\text { CB (ASEBIR) } \\
\text { C: (ICM and TE) } \\
\text { CC (Garder), CC - DC - CD } \\
\text { (Veeck), } 333 \text { (Istanbul consensus), } \\
\text { AC-AD (ASEBIR) }\end{array}$} \\
\hline & 2 & 1 or 2 & 2 & & \\
\hline & 3 & 3 & 2 or 3 & & \\
\hline & 4 & 3 & 3 & & \\
\hline & 5 & 4 & 4 & & \\
\hline & 6 & 5 & 4 & & \\
\hline & - & 6 & - & - & \\
\hline \multirow{4}{*}{ ICM } & $\mathrm{A}$ & $\mathrm{A}$ & 1 & $\mathrm{~A}$ & \\
\hline & $\mathrm{B}$ & $\mathrm{B}$ & 2 & $\mathrm{~B}$ & \\
\hline & $\mathrm{C}$ & $\mathrm{C}$ & 3 & $\begin{array}{c}\mathrm{C} \\
\text { (Indifferent) }\end{array}$ & \\
\hline & - & $\mathrm{D}$ & - & $\mathrm{D}$ & \\
\hline \multirow{4}{*}{$\mathrm{TE}$} & $\mathrm{A}$ & $\mathrm{A}$ & 1 & $\mathrm{~A}$ & \\
\hline & B & B & 2 & $\mathrm{~B}$ & \\
\hline & $\mathrm{C}$ & $\mathrm{C}$ & 3 & $\mathrm{C}$ & \\
\hline & - & $\mathrm{D}$ & - & $\mathrm{D}$ & \\
\hline
\end{tabular}


In the case of expansion, the Gardner system includes a score of 1-6 evaluating the blastocyst from the start of the expansion $(<50 \%$, grade 1 ) to the hatched state (grade 6 ). The ASEBIR system also considers the expansion of the blastocyst from the beginning of the expansion; however, it does not give a score to this characteristic. In the Veeck's system, the score 1 would not correspond to Gardner's or Istanbul Consensus, because according to Veeck's characteristics, these embryos would be a cavitated morula. In addition, the Veeck system includes grade 6, given to hatching or hatched blastocysts, preimplantation genetic diagnosis.

Regarding the ICM and TE, ASEBIR and Veeck systems include the " $D$ " score when they present degenerative cells. It should be noted that in the ASEBIR system, the " $C$ " score of the ICM is indifferent in the final evaluation of the blastocyst and the TE has a greater importance.

Although the classification of blastocysts is based on the morphology of ICM, TE, as well as the expansion of the blastocyst cavity (Balaban et al., 2006; Racowsky et al., 2010; Hill et al., 2013), these classification systems may be difficult for patients to understand when discussing their embryonic quality prior to the transfer of an embryo (Heitmann et al., 2013). Therefore, other systems have been developed, such as the Sjoblom system, that considers the classification of the expansion, ICM and TE together, assigning $\mathrm{A}, \mathrm{B}$ or $\mathrm{C}$ to the blastocyst score.

In general, $48.3 \%$ of the embryologists surveyed considered that the classification system used was easy (Figure 3 ), the rest considered that the difficulty of the systems was medium to high (Figure 5). It should be mentioned that the assessment of difficulty was not due to years of professional practice as an embryologist. Eightytwo percent of the embryologists who categorized their blastocyst qualification system with a difficulty of 3,4 or 5 , had over 10 years of experience. Although potentially this could be irrelevant, because the survey assessed only the years in practice of an embryologist, not the time of experience in blastocyst classification.

Considering the variability of the score between the different blastocyst grading systems and possible inter- observer confusions that can present at the moment of blastocyst scoring with different systems, we asked about the possibility of unifying the embryo classification system in the region, in which $88.3 \%$ of the respondents agreed. However, it would be important to know who in this group of embryologists would be willing to modify their blastocyst classification system and adapt it to a common system for the region. This is a question that was not included in the survey.

Although this study includes only 60 embryologist responses, it gives precedence to investigate the probabilities of being able to establish a consensus regarding blastocyst score systems among Latin American countries, which should be based on the different classification systems used by assisted reproduction centers of our region. This consensus would provide the necessary recommendations for the centers and would be an important guide for assisted reproduction centers that have not yet established a fixed blastocyst qualification system. To achieve this, it would be convenient to collect more information on the different classification criteria of blastocysts used by our embryologists.

\section{CONCLUSION}

Seven different blastocyst classification systems were reported in 12 countries of Latin America. Although the group of embryologists surveyed use different blastocyst classification systems, most of them consider that the embryo score system should be unified in their countries as well as in the region.

\section{CONFLICT OF INTERESTS}

The authors have no conflict of interests to report.

\section{Corresponding author:}

Tatiana Puga-Torres

Centro Nacional de Reproducciónn Asistida - INNAIFEST

Guayaquil - Ecuador

E-mail: fertilidad-innaifest@hotmail.com
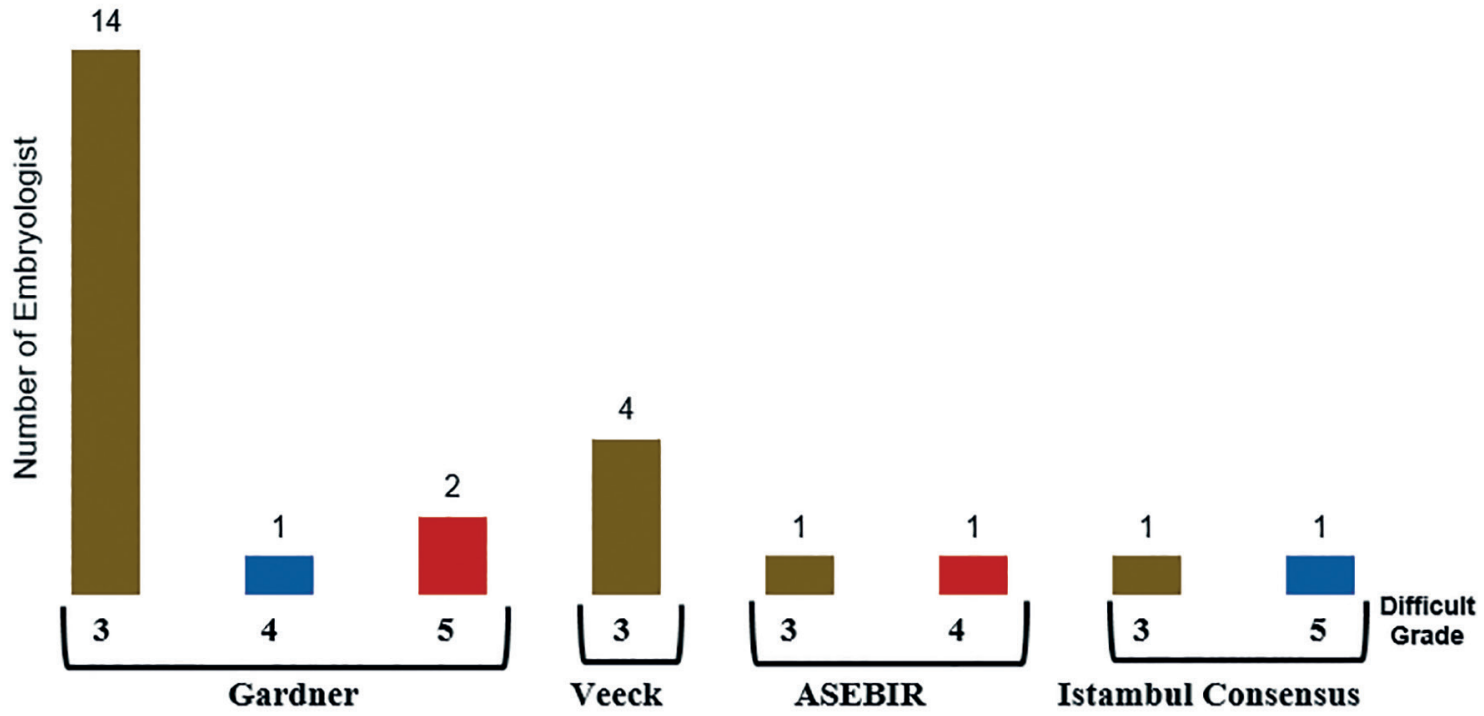

Figure 5. Qualification Systems with 3-4-5 level of perceived difficulty and number of embryologists. 


\section{REFERENCES}

Alpha Scientists in Reproductive Medicine and ESHRE Special Interest Group of Embryology. The Istanbul consensus workshop on embryo assessment: proceedings of an expert meeting. Hum Reprod. 2011;26:1270-83. PMID: 21502182 DOI: 10.1093/humrep/der037

Associación para el Estudio da la Biologia de la Reproducción (ASEBIR), ed. Criterios ASEBIR de Valoración Morfológica de Oocitos, Embriones Tempranos y Blastocistos Humanos. Cuadernos de Embriologia Clínica. Madrid: ASEBIR; 2015.

Balaban B, Yakin K, Urman B. Randomized comparison of two different blastocyst grading systems. Fertil Steril. 2006;85:559-63. PMID: 16500319 DOI: $10.1016 /$ j.fertnstert.2005.11.013

Crosby J, Mackenna A. Blastocyst selection criteria: towards day five single embryo transfer. JBRA Assist Reprod. 2013;17:162-5. DOI:10.5935/1518-0557.20130054

Gardner DK, Lane M, Stevens J, Schlenker T, Schoolcraft WB. Blastocyst score affects implantation and pregnancy outcome: towards a single blastocyst transfer. Fertil Steril. 2000;73:1155-8. PMID: 10856474 DOI: $10.1016 / \mathrm{S} 0015-0282(00) 00518-5$

Gardner DK, Surrey E, Minjarez D, Leitz A, Stevens J, Schoolcraft WB. Single blastocyst transfer: a prospective randomized trial. Fertil Steril. 2004;81:551-5. PMID: 15037401 DOI: 10.1016/j.fertnstert.2003.07.023

Gianaroli L, Racowsky C, Geraedts J, Cedars M, Makrigiannakis A, Lobo RA. Best practices of ASRM and ESHRE: a journey through reproductive medicine. Fertil Steril. 2012;98:1380-94. PMID: 23102857 DOI: 10.1016/j.fertnstert.2012.07.1164

Heitmann RJ, Hill MJ, Richter KS, DeCherney AH, Widra EA. The simplified SART embryo scoring system is highly correlated to implantation and live birth in single blastocyst transfers. J Assist Reprod Genet. 2013;30:563-7. PMID: 23443889 DOI: $10.1007 / \mathrm{s} 10815-013-9932-1$
Hill MJ, Richter KS, Heitmann RJ, Graham JR, Tucker MJ, DeCherney $A H$, Browne PE, Levens ED. Trophectoderm grade predicts outcomes of single-blastocyst transfers. Fertil Steril. 2013;99:1283-9.e1. PMID: 23312233 DOI: 10.1016/j.fertnstert.2012.12.003

Hossain A, Phelps J, Agarwal A, Sanz E, Mahadevan M. A Review of The Society for Assisted Reproductive Technology Embryo Grading System and Proposed Modification. Int J Fertil Steril. 2016;10:141-7. PMID: 27441045 DOI: 10.22074/ijfs.2016.4956

Mackenna A, Crosby J, Zegers-Hochschild F. Sibling embryo blastocyst development as a prognostic factor for the outcome of day-3 embryo transfer. Reprod Biomed Online. 2013;26:486-90. PMID: 23523378 DOI: $10.1016 /$ j.rbmo.2013.02.003

Matsuura K, Hayashi N, Takiue C, Hirata R, Habara T, Naruse $\mathrm{K}$. Blastocyst quality scoring based on morphologic grading correlates with cell number. Fertil Steril. 2010;94:1135-7. PMID: 20079898 DOI: 10.1016/j.fertnstert.2009.11.003

Nasiri N, Eftekhari-Yazdi P. An overview of the available methods for morphological scoring of pre-implantation embryos in in vitro fertilization. Cell J. 2015;16:392-405. PMID: 25685730 DOI: 10.22074/cellj.2015.486

Racowsky C, Vernon M, Mayer J, Ball GD, Behr B, Pomeroy KO, Wininger D, Gibbons W, Conaghan J, Stern JE. Standardization of grading embryo morphology. Fertil Steril. 2010;94:1152-3. PMID: 20580357 DOI: $10.1016 /$ j.fertnstert.2010.05.042

Richardson A, Brearley S, Ahitan S, Chamberlain S, Davey T, Zujovic L, Hopkisson J, Campbell B, Raine-Fenning N. A clinically useful simplified blastocyst grading system. Reprod Biomed Online. 2015;31:523-30. PMID: 26283016 DOI: $10.1016 /$ j.rbmo.2015.06.017

Santos Filho E, Noble JA, Poli M, Griffiths T, Emerson G, Wells $D$. A method for semi-automatic grading of human blastocyst microscope images. Hum Reprod. 2012;27:26418. PMID: 22736327 DOI: 10.1093/humrep/des219

Veeck L, Zaninovic N. An Atlas of Human Blastocysts. New York, London: Informa Healthcare; 2003. 